derzeit in den vier untersuchten Branchen unter anderem mittels Stakeholder-Surveys gearbeitet. Daraus sollen auch Anregungen für die Unternehmen und die Unternehmensbewertung abgeleitet werden.

\section{$\checkmark$ Fazit}

Die Transparenz auf Seiten der Anbieter von nachhaltigen Finanzprodukten und der Nachhaltigkeitsperformance der Anlageobjekte ist eine essenzielle Voraussetzung, um die vorerst leisen Signale für eine nachhaltige Entwicklung dieses Marktsegments zu erkennen und zu verstärken. Diese Transparenz dient zwei Bedürfnissen zugleich: Sie dient dem sozial oder ökologisch interessierten Anleger bei der Entscheidung für entsprechende Anlagemöglichkeiten. Und sie dient dem pragmatischen
Investor, der von der langfristigen Relevanz sozialer und ökologischer Herausforderungen für die Aktienperformance überzeugt ist.

\section{Anmerkungen}

(1) Das Projekt findet mit Förderung des Bundesministeriums für Bildung und Forschung unter der Schirmherrschaft von UNEP-Direktor Prof. Klaus Töpfer gemeinsam mit 15 Unternehmen, davon 13 aus dem DAX 30, statt. Das Handlungsziel ist die Entwicklung einer Informations-Plattform zum nachhaltigen Investment. Vgl. von Flotow, Paschen/ Häßler, Rolf-D./ Schmidt, Johannes in Zusammenarbeit mit Graulich, Katrin/ Hochfeld, Christian/ Rennings, Klaus/ Schmidt, Beate/Schröder, Michael: Umwelt- und Nachhaltigkeitstransparenz für Finanzmärkte - Stand und Perspektiven, Oestrich-Winkel 2002.

(2) Die Plattform ist seit 17.2.2003 online: www.nachhaltiges-investment.org
(3) Vgl. Plinke, Eckhard: Aktienperformance und Nachhaltigkeit, Bank Sarasin, Basel 2002; Ziegler, Andreas/ Rennings, Klaus/ Schröder, Michael: Der Einfluss ökologischer und sozialer Nachhaltigkeit auf den Shareholder Value europäischer Aktiengesellschaften, ZEW Discussion Paper No. 02-32, Mannheim 2002.

\section{Die Autorlnnen}

Dr. Paschen von Flotow und Rolf Hässler sind am Institut für Ökologie und Unternehmensführung (IÖU) an der European Business School (ebs) tätig. Kontakt: IÖU an der ebs e.V., Burgstraße 4, 65375 Oestrich-Winkel, E-Mail: flotow@instoec.de Kathrin Graulich und Christian Hochfeld sind wissenschaftliche Mitarbeiter des Öko-Instituts. Kontakt: Öko-Institut e.V., Novalisstraße 10, 10115 Berlin, E-Mail: c.hochfeld@oeko.de

The Role of Eurosif in shaping Socially Responsible Investment in Europe

\title{
Catalyst for the Necessary Changes
}

\section{Das ethisch-ökologische Investment tritt in eine neve Phase. Es geht nun um die Entwicklung von Professionalität, Glaubwürdigkeit und Tragfähigkeit. Hierzu müssen in den kommenden Jahren Kooperationen zwischen Stakeholdern ver- stärkt, eine europäische Regulierung entwickelt sowie Normen und gute Bei- spiele verbreitet werden. Hierzu kann Eurosif, ein vor kurzem gegründeter Dachverband für nachhaltige Geldanlagen, einen wichtigen Beitrag leisten. Ein Hauptziel ist die Entwicklung von Transparenzrichtlinien.}

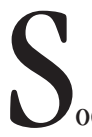

Von Matt Christensen und Sylvain Guyoton Responsible Investment (SRI) is increasingly becoming part of mainstream financial analysis. Several investment banks have recently launched services in this area and the SRI Disclosure Guidelines launched by the UK's Association of British Insurers in 2001, whose members represent 25 per cent of the UK stock market, bears witness to this. Pensions reform across Europe and increasing numbers of individuals saving via share ownership are leading to an increase in the size of the equity markets within the EU. As of April 2002, the European asset management market, for the top 400 asset managers alone, was responsible for 24 trillion.

Thus, the financial sector plays a major role in the European economy. Further, many financial service providers now operate across Europe, driving the importance of a pan-European policy framework for the sector. European policy-ma- kers have realised that there is a growing interest to harness the potential of shareholders to promote responsible and sustainable corporate practice for advancing social and environmental progress. Indeed, the European Commission has recognized the potential for SRI in its July 2002 Communication on Corporate Social Responsibility (CSR) (1) and through support for the European Sustainable and Responsible Investment Forum (Eurosif). However there is much work needed to integrate inter-departmental stances to produce a coherent policy framework. Eurosif was launched in 2001 by five national SRI forums with support from Directorate General Employment and Social Affairs. Eurosif's creation was driven by the interests of institutional investors, NGOs and the European Commission.

\section{Eurosif's Objectives}

Eurosif's overall aim is to aid the integration of social, environmental and ethical issues into Europe- an financial services and to provide a multi-stakeholder network to share best practices on SRI. In order to reach this objective, Eurosif will:

- build an active European network for all organisations interested in promoting SRI,

- encourage CSR and sustainability by promoting active shareholding,

- initiate and publish research about legislation, policies and practices relating to the effective integration of social, environmental and ethical issues in the European investment market, and - actively expand the European network of National SRI organisations.

At the moment there are five national organisations: U.K., Netherlands, German speaking countries, Italy and France. Recent Eurosif activities in 2002 included calling for the inclusion of a disclosure measure in the draft Directive for Institutions for Occupational Retirement Provision (IORP Directive), launching the development of pan-European transparency guidelines for retail SRI funds and calling for investor representation at the EC's Multi-stakeholder Forum on CSR.

The objectives for 2003 are manifold. First, Eurosif aims to enhance its media presence and exposure. Second, Eurosif will be responsible for developing the retail SRI funds transparency guidelines into a pilot phase by summer 2003. Finally, the organisation will publish a report on the status of the European SRI market.

\section{New Transparency Guidelines}

Eurosif is developing a set of voluntary guidelines on transparency for retail sustainable and responsible funds. Eurosif believes this project comes at a key stage of the sector's expansion. The Eurosif 
transparency guidelines will be based on the current best practices and on existing guidelines developed by the Dutch SRI organisation VBDO. The overriding aims are to ensure that retail SRI funds are accountable to all stakeholders, and to preserve the reputation of the SRI sector. We hope that signatories to the guidelines will demonstrate leadership in transparency, openness and accountability for the retail SRI sector. Finally, the guidelines will serve not only the SRI community but also the mainstream financial service providers interested in better reflecting their transparency. Potentially, Eurosif transparency guidelines will pre-empt the development of different national initiatives as well as answer the European Commission's call for increased disclosure. The EC's Directorate General for Employment and Social Affairs is supporting the development of the guidelines though grant funding for Eurosif.

Reflecting Eurosif's multi-stakeholder philosophy, the organisation aims to conduct an open and inclusive consultation process. This initial consultation will feed into the pilot guidelines to be launched in mid 2003. It is hoped that top retail SRI funds across Europe will commit to a trial in 2003/2004 with their comments being used to inform the long-term development.

\section{- Potential Benefits}

- Reputation - Retail SRI funds are positioned as forerunners in concerns over transparency and best practice on social responsibility. Thus, the reputation of SRI is inherently linked with the reputation of retail funds. The voluntary transparency guidelines will aid consumer and public understanding of retail SRI products, helping to grow confidence in the sector. Application of the guidelines will ensure that the sector's reputation is not damaged by negative publicity about poor disclosure (2). This will become increasingly important as new funds are launched across Europe encompassing a diversity of approaches (see the contribution by Bammert).

- Accountability - Greater transparency from retail SRI funds should increase accountability to stakeholders as well as set a positive example to companies and other stakeholders.

- Efficiency and effectiveness - Disclosure from SRI funds may help companies and SRI research to better understand the needs of socially responsible investors. In turn, this should result in improvements of the quality and relevance of social and environmental performance communications provided for investors. Increased trans- parency around SRI criteria and investment policies may provide performance data to help determine the most effective SRI policies and techniques for improving corporate behaviour. Greater trust should also help growing the total amount of retail SRI in Europe, thereby increasing the potential influence of SRI funds to improve corporate social and environmental behaviour and furthering the EC's objectives on corporate social responsibility.

- Publicity - Further to press releases from Eurosif in 2002, we have witnessed a high level of interest in the transparency guidelines from the financial press and other publications. It is hoped that the launch of the Eurosif transparency guidelines will attract increased coverage of SRI.

\section{- Conclusion}

SRI is a market driven way to advance good corporate governance, sustainable development and other positive social and environmental aims. It is imperative that corporations, investors and policymakers work together to harness this potential towards creating a more sustainable Europe. As an illustration, the development of retail SRI funds transparency guidelines involves all major stakeholders and acts as the type of initiative that can help Europe become more cohesive in its efforts towards sustainability. Given the intensity of the SRI movement, it would pose a risk not to start coming together on some of the higher profile SRI initiatives in order to generate learning and some common frameworks across geographic markets. Our hope is that the sector will embrace these efforts and make them successful.

\section{References}

(1) Com (2002) 347 final.

(2) The New Economics Foundation challenged the SRI sector to set baseline quality standards for accountability, transparency, responsiveness and compliance. See Mayo, Ed/ Doane, Deborah: An Ethical Door Policy: How to avoid the erosion of ethics in SRI. New Economics Foundation, London 2002.

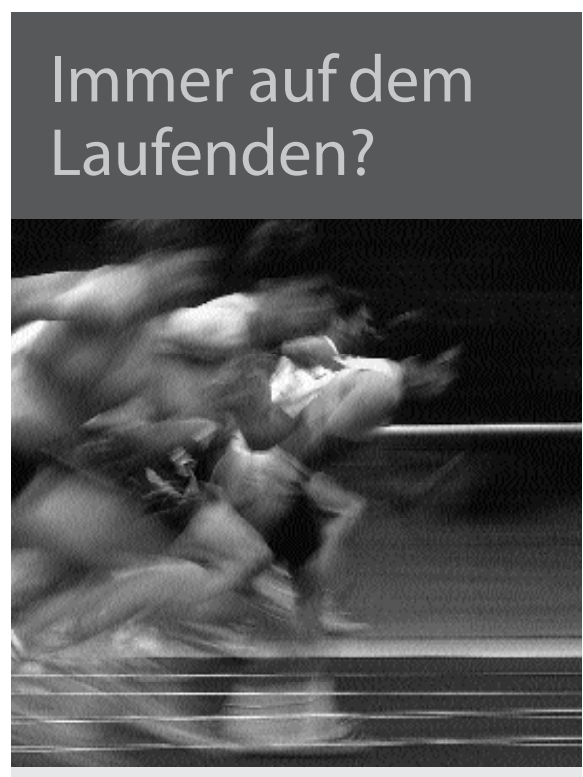

punkt.um!

Der Umweltinformationsdienst punkt. um liefert die entscheidenden News zu Umwelt und Nachhaltigkeit in Politik, Wirtschaft, Gesellschaft - jeden Monat kompakt und übersichtlich.

Das Magazin informiert über aktuelle Entwicklungen und analysiert Hintergründe.

Ein Dossier berichtet ausführlich über das Nachhaltigkeitsthema des Monats.

Der Medienspiegel gibt einen Überblick über literarische Neuerscheinungen und fasst die wichtigsten Artikel aus über 150 Publikationen und neuen Medien.

- Regelmäßig erscheinen die Toolbox für Agenda-Moderatorlnnen und die Ökopäd-News mit hilfreichen Anregungen für praktische Umweltbildungsarbeit.

\section{INTERESSIERT?}

\section{Einzelheft $9 €$}

Abopreis für 12 Ausgaben $59 €$ (+ Online-Abo $88,50 €$ ) Institutionen $95 €$ (+ Online-Abo 142,50€)

Studenten $45 €$ (+ Online-Abo $67,50 €$ )

Zu beziehen bei:

punkt.um Leserservice, CONSODATA ONE-TO-ONE

Semmelweisstraße 8, D-82152 Planegg

Fon $++49 /(0) 89 / 85709-155$, Fax -131

E-Mail: kontakt@oekom.de

oder kostenlose Leseprobe unter: 
(c) 20I0 Authors; licensee IÖW and oekom verlag. This is an article distributed under the terms of the Creative Commons Attribution Non-Commercial No Derivates License (http://creativecommons.org/licenses/by-nc-nd/3.o/), which permits unrestricted use, distribution, and reproduction in any medium, provided the original work is properly cited. 